\title{
Norwegian social epidemiology during 200 years
}

\author{
Steinar Krokstad and Erik Reidar Sund \\ HUNT Research Centre, Department of Public Health and General Practice, \\ Norwegian University of Science and Technology, Levanger, Norway \\ E-mail: steinar.krokstad@ntnu.no
}

This is an open access article distributed under the Creative Commons Attribution Licence, which permits unrestricted use, distribution, and reproduction in any medium, provided the original work is properly cited.

\section{INTRODUCTION}

Social epidemiology has been defined as The branch of epidemiology that studies the social distribution and social determinants of states of health (1). Whereas traditional epidemiology is primarily concerned with health related factors at the individual level, social epidemiology is more concerned with the health conditions between social groups in the population or between populations. Thus, social epidemiology is highly relevant for public health and health policy (S. Westin, this issue), while epidemiology, concerned more with individual risk or resilience is most relevant for treatment of specific diseases within the health services. The epidemiologist Geoffrey Rose (1926-1993) was instrumental in emphasizing the difference between the determinants of individual cases and the determinants of incidence rates, thereby shifting the focus from individuals to populations (2). George Davey Smith recently highlighted main challenges with the individual focus, personalized medicine, and the desire to predict individual destinies - randomness and individual life's coincidences (3). However, when comparing groups of populations or entire populations in social epidemiology, average health can be predicted in a more expected manner based on information on the socioeconomic conditions people are living under; the social determinants of health. Social epidemiology attained its name in English in 1950 and is by its definition truly cross-disciplinary, encompassing both the medical, behavioural as well as the social sciences.

In recent years, social epidemiologists have been much occupied with the socioeconomic gradient in health, extending from top to bottom of the social hierarchy, and showed that it is not a poverty threshold that separates those with poor versus good health (4). In addition, research has shown that poor people living in poor neighborhoods are likely to have poorer health than equally poor people living in more affluent neighborhoods $(5,6)$. But are these observations in fact new? Or is it that researchers once again have been willing to engage with questions initially raised during the formative days of epidemiology as a discipline, in the early 19th century (7)?

\section{Pioneers in NorWegian Social EPIDEMIOLOGY}

Eilert Lund Sundt (1817-1875) was a theologist and sociologist (http://no.wikipedia.org/wiki/Eilert_Sundt), known for his work on mortality, marriage and other subjects among the working class (L.M. Irgens, this issue). He was born into a large family of thirteen children, and he had to work during his childhood to help make ends meet in the family. He lived close to all kinds of people in a small community. These experiences probably affected his research interest later in his life, the health effects of poverty, harsh working conditions and issues associated with the transition from the farm culture to business and industry in the 19 th century. Sundt had a variety of research interests like the conditions in prisons, living conditions for gypsies, causes of death, conditions of prostitutes, causes of suicide, manual workers' living and working conditions, household hygiene and administration of poverty laws. From 1857 to 1866 Eilert Sundt was editor of Folkevennen ("Friend of the People"), for which he wrote a number of his most influental articles. A true social epidemiologist.

The physician Kristian Feyer Andvord (1855-1934) described the decline in mortality from tuberculosis by birth cohort. Due to the time in which he undertook his research it has been argued that birth cohort analyzes is a Norwegian invention (8). Andvord assumed that mortality changes were due to changes in immunity in the population. However, the prevailing view today is that the successive reduction in mortality was due to improved socio-economic living conditions (8). The study of cohort effects in contrast to effects of age is still a very interesting approach in many settings.

In the 1970s, the Norwegian physician Anders Forsdahl (1930-2006) published ecological analyzes of the relationship between infant mortality in the early 1900s and mortality from cardiovascular disease in the 1960s (9). Forsdahl hypothesized that poor living conditions in early life increaseed the risk of disease later in life in a life-course perspective. Another explanation for the findings is of course that sub-optimal socioeconomic living conditions over the life-course increases the risk of disease through cumulative impact, without mechanisms like "biological programming" involved (10).

\section{THE PRELUDE TO TODAY'S SOCIAL EPIDE- MIOLOGY IN NORWAY, 1950S TO 1980S}

\section{Occupational health inequalities}

In England, data on mortality by occupational class have been available from the 1850s (11). In 1980, the 
Black report was published in England, which showed marked social inequalities in health by occupational status (12). The report, which was initially withheld by the incoming Thatcher government, became a milestone for the interest in social inequalities in health and social epidemiology. In Norway however, occupational data had not been systematically recorded up to the 1950s. Borgan and Kristofersen published the first Norwegian data for men in different occupations in 1986 (13). In 1976, Holme and colleagues completed a study that was based on the common perception that coronary heart disease was a "manager's disease". With data from the Oslo Study they found the opposite, and examined whether these social inequalities in coronary heart disease mortality could be explained by differences in conventional risk factors (14). Other studies have also analysed the contribution of health behaviours in explaining the social gradient in health. The most wellknown study by Marmot and colleagues, found that a substantial social gradient in health still remains after adjusting for (un)healthy lifestyles (15).

\section{Geographical health inequalities}

The description of geographical variation in mortality rates was the first way of describing social health inequalities in Norway. Back in 1855, Eilert Sundt published mortality rates for deaneries (church parishes) for the period 1831 to 1850 (16). A century later, Statistics Norway published regional estimates of mortality data (17) and a number of publications have appeared ever since $(18,19)$. The Norwegian Cancer registry published the world's first atlas of cancer incidence in 1985 (20). A general finding in all these publications has been the discovery of geographical differences in health at multiple scales (or geographical levels) from the topmost county level down to small areas. Small area health variations within neighborhoods in Oslo have been consistently reported (20-22). Ongoing public health monitoring is also conducted at the Norwegian Institute of Public Health where public health indicators are published for both municipalities and counties. A similar project is conducted with data from the Nord-Trøndelag Health Study (HUNT) and the results are readily available on the web.

\section{TODAY's SOCIAL EPIDEMIOLOGY IN NORWAY}

The first Norwegian textbook in social epidemiology was published in 2009 (23), and was edited by four central Norwegian social epidemiologists, John Gunnar Mæland, Jon Ivar Elstad, Øyvind Næss and Steinar Westin. This marked that social epidemiology had expanded and had become an established field in Norwegian epidemiology. The book contributed to a nice overview of social epidemiological research, especially in Norway. In this discipline, that primarily can be seen as an interdisciplinary field between medicine and the social sciences, a number of subject-specific terms are used in social epidemiology.

In 2008, in the WHO Commission on Social Determinants of Health's final report, the Member States was urged to assess the impact of public policies on equitable distribution of health (24). As part of the Norwegian national strategy to reduce social inequalities in health (25), one of Norway's most influental social epidemiologist, Espen Dahl, was asked to develop such an knowledge overview for our country. This report was published in 2014 (26).

\section{Social inequalities in health and risk factors in Norway}

The presence of social health inequalities in Norway is well documented, both with national data (27) (Figure 1 ), as well as with data from large regional health surveys (28). The main theories that underpin our understanding of social inequalities in health are presented in Textbox 1. Inequalities in mortality seem to have increased during the latest decades, whereas studies with more subjective health measures show stable inequalities $(27,28)$.

People from lower socio-economic groups are more likely to smoke, drink alcohol more excessively, are less physically active and have unhealthier diets. Ernstsen and colleagues analysed trends in socioeconomic inequalities in four modifiable ischaemic heart disease risk factors (smoking, diabetes, hypertension and high total cholesterol) over three decades among Norwegian

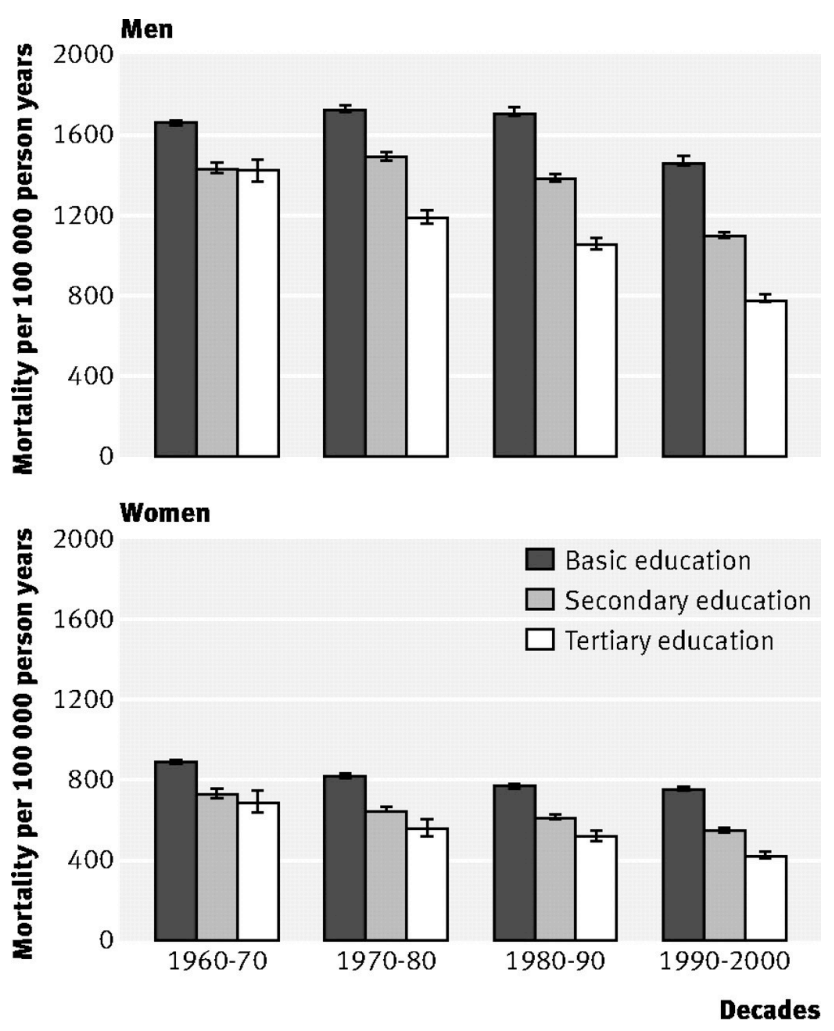

Figure 1. Bjørn Heine Strand et al. showed in a BMJ paper (27) that the educational inequalities in mortality had increased from the 1960ies to the 1990ies in Norway. Figure reproduced from [B.H. Strand et al., BMJ 2010; 340: c654] with permission from BMJ Publishing Group Ltd. 


\section{Textbox 1. Mechanisms behind social inequalities in health}

\section{Social biology}

Human beings are both social and biological. Embodiment, refers to how we incorporate, biologically, the world in which we live, including our societal and ecological circumstances (32). Psychosocial factors may affect health in two ways. Directly causing biological changes which predispose to disease, or indirectly via behaviours such as smoking and diet, which in turn affects health (33).

\section{The life course perspective}

The idea that a person's experiences over a life time can have cumulative effects on their health is a central idea within social epidemiology. The latency model of early life experiences hypothesis that experiences in utero or early life affect cardiovascular and other diseases in adulthood. Another theory suggests that the accumulation of social advantage and disadvantage throughout the life course affects adult health (9). A third suggested pathway is one in which parental social class and educational qualifications are important because they determine the socioeconomic circumstances in which the offspring lives and works in adult life (34).

\section{The neo-material perspective}

It is very likely that a combination of macro-economic factors (economic growth) and public policies (public health measures) have contributed to a large overall decrease in mortality rates and increase in life expectancy during many decades. Some researchers argue that, even today, economic and political processes are the fundamental determinants of health and disease (35). Neo-liberal (market oriented) policies which increases income inequalities and favor the dismantling of the welfare state may contribute to widen existing social inequalities (36).

\section{The psychosocial perspective}

If the social environment is important for health, this is likely to be manifested as social inequalities in health. People from better social environments with greater access to socio-economic resources are likely to have better health. Some researchers argue that health inequalities arise because of the psychosocial consequences of differences in wealth, power and prestige $(35,37)$. In the book The Status Syndrome, Michael Marmot argues that the mental benefits of "being in control" of one's life, might be a key factor for understanding health disparities, because autonomy in this sense is related to our socio-economic position (38). Richard Wilkinson has also been an advocate for the psychosocial perspective. Wilkinson has studied the relationship between income inequality within countries and effects on a wide range of social and health conditions. He describes in his works the psychosocial consequences of large social differences for people down the social ladder (39).

\section{The role of selection}

Both Espen Dahl and Jon Ivar Elstad have contributed substantially to the understanding on how health-related selection of different social groups may explain the relationship between social position and health (40-42). The theory postulates that at least some of the inequalities are caused by people with poor health drifting downwards on the social ladder, while people with good health tend to move up the hierarchy. In general, researchers have found that selection processes is weak explanation for the higher death risk in the lower income deciles (43). The most marked health related social selection processes in society today, nevertheless seems to be the selection out of working life for people with health problems $(44,45)$.

\section{The fundamental cause}

Link and Phelan (46) proposed that socioeconomic status is a "fundamental cause" of health inequalities, that socioeconomic disparities endure despite changing mechanisms because socioeconomic status embodies an array of resources, such as knowledge, prestige, power, money, and favorable social connections, that protect health no matter what mechanisms are relevant at any given time. To test this theory Mackenbach et al. compared the extent of inequalities in mortality between more and less preventable causes of death in 19 European populations, and assessed whether inequalities in mortality from preventable causes was larger in countries with larger resource inequalities. The results provided some support for the theory of "fundamental causes". However, the absence of larger inequalities for preventable causes in Southern Europe and for injury mortality among women indicate that further empirical and theoretical analysis is necessary to understand when and why the additional resources that a higher socioeconomic status provides, do and do not protect against prevailing health risks (47).

\section{The ecosocial perspective}

Even the fundamental cause theory cannot conceptualize all factors that might be involved producing health disparities. In order to conceptualize the myriad of social and biological processes actually resulting in embodiment and its manifestation in populations' epidemiological profiles, Nancy Krieger proposed the ecosocial perspective (48). In ecosocial theory, its fractal image integrates each level of biological, ecological and social organization, from the cell to organ, individual, family, community, population, society to ecosystem. The goal is not a grand and encompassing theory to explain everything, but to generate a set of testable principles useful for guiding specific research ranging from paleontology to molecular biology. 
middle-aged women and men, and found widening absolute educational inequalities in smoking and diabetes over the last three decades (29). Norway has a poor standing when it comes to social inequalities in smoking (30), and this may constitute part of the explanation behind fairly high relative health inequalities in Norway despite the marked social democratic politics in the postwar years (31).

\section{Social inequalities in work related disability}

Occupation and work can have a major impact on people's health in the short and long term. The workplace may offer health promotive as well as harmful risk factors (49). Work related disability will have their causes both within and outside working life (50). Norwegian studies suggest marked social gradients in sickness absence and long term work related disability, more so than for both illness and mortality (51). Nilsen and colleagues aimed to disentangle factors behind the marked educational inequalities in disability pensioning. They found that both illness, occupational, psychosocial, and behavioural factors explained some of the educational inequalities in later disability pensioning. However, as observed in many other studies, considerable inequalities remained unexplained after accounting for these factors (52).

\section{Social inequalities in the health services}

No one has probably contributed more to stimulate research on social inequalities in health services than the British GP Julian Tudor Hart. The Inverse care law proposed by Hart in 1971, has since been widely adopted: The availability of good medical care tends to vary inversely with the need for it in the population served. This inverse care law operates more completely where medical care is most exposed to market forces, and less so where such exposure is reduced. The market distribution of medical care is a primitive and historically outdated social form, and any return to it would further exaggerate the maldistribution of medical resources $(53$, p. 405$)$. Vikum and colleagues investigated socio-economic inequalities in health care utilization from the 1980s and through the last three decades using the HUNT Study. The data suggested that previous socio-economic inequalities in GP utilization had diminished, that there was an equal utilization of in-patient care but that highly educated people were more prone to utilize hospital outpatient consultations throughout the three decades (54). Data from the Tromsø Study have largely confirmed the evidence (55).

Another important international contribution to social epidemiological research on health services in Norway came from John Wennberg in 2010 (56). He documented tremendous geographic variation in healthcare in the US. Wennberg distinguished between effective/ necessary, preference-sensitive and supply-sensitive health services, and showed that health services that is indisputable good for health only constitute about $15 \%$ of the total health care economy in the US. In particular
Olav Helge Førde has contributed to research in this field in Norway, and have dokumented variations in clinical practice in Norway that cannot be justified scientifically (57).

\section{RESEARCH ON SOCIAL, CULTURAL AND SOCIETAL DETERMINANTS OF HEALTH}

\section{The welfare state}

All people need social protection across the lifecourse, as young children, in working life, and in old age. People also need protection in case of illness, disability, and loss of income or work (24). It can be argued that social legislation and welfare policies have had a much greater impact on public health than medical innovations (58).

However, welfare sceptics claim that high welfare spending and labour market regulations benefit neither the society nor the disadvantaged groups. Ketil van der Wel et al. used European data from 2005 covering 26 European countries linked to country characteristics derived from Eurostat and OECD. Using multilevel analyses they found that comprehensive welfare states had lower absolute and relative social inequalities in sickness, as well as more favorable general rates of non-employment. They concluded that welfare resources appear to trump welfare disincentives (59).

In order to highlight other roles of welfare state programmes important to population health, Swedish social epidemiologists has been in front, in particular with the NEWS project (60). There is overwhelming empirical support to claim that social spending is causally related to poverty (61). Welfare state matters for poverty, and poverty matters for child mortality. Regime type as such has been found to have a clear influence on child mortality, even when controlling for GDP and social spending. In other words, the result suggests that there are several regime-specific factors that are important for child health (62).

\section{Social networks, social support and social cohesion}

The effect of social support and social networks on health has been studied since at least the 19th century when Durkheim investigated links between social integration and suicide. In Norway, Odd Steffen Dalgard has played a significant role for social epidemiological research in this field (63). Based on the Oslo Study in 1975-76 and data on mortality and causes of death from Statistics Norway, Dalgard and colleagues found that low social participation, and to a lesser extent, few close relationships and external locus of control, were associated with increased mortality (64). Regarding mental health, Dalgard et al. found that women with no social support were more vulnerable for depression than men without support when exposed to negative life events (65).

\section{Social capital}

The term "social capital" was in occasional use in the social sciences from about 1890 , but became more 
widely used in the late 1990s after the British social epidemiologist Richard Wilkinson published his hotly debated "Unhealthy societies. The Afflictions of Inequality" in 1996 (66). Attempts to define social capital have focused on social capital as a resource for public good or for the benefit of individuals. Putnam and Coleman suggested that social capital would facilitate co-operation and mutually supportive relations in communities and nations, good for public health and a valuable resource for combating social disorders inherent in modern societies, for example crime. Researchers focusing on the individual benefit derived from social capital like Bourdieu, individual actors might benefit from social capital to increased personal access to information, skill and power (67). Sund and colleagues found that the level of trust in neighborhoods, a contextual construct, was positively associated with good self-rated health and a lower risk of depression with data from the HUNT Study (68) while van der Wel fond no association between social capital and self-rated health between administrative areas in Oslo (69).

\section{Discrimination, poverty and vulnerable groups}

Vulnerable groups are often overrepresented in the non-responder group in large general health surveys. The participation in the HUNT Study in 2006-08 for example, increased according to socioeconomic status, and social insurance recipients was the group with the lowest participation rates (70). As a consequence, many general surveys tend to underestimate social health inequalities, and in order to study health in vulnerable groups other research designs are often required.

Vulnerable and marginalized groups in society carry a large burden of health problems. Many health inequalities are rooted in fundamental social structural inequalities, which are related to different forms of discrimination in society (71). Historically, women in Norway and in many societies have been discriminated in terms of lack of voting rights, barriers to education and more direct harmful physical abuse. In Norway, the Sami people have been subject to discrimination for a long time. The Norwegian society is now increasingly multicultural, and different ethnic groups may experience varying degrees of discrimination in employment and health services (72). There is currently a scarcity of social epidemiological research in this field in Norway, but there are important exceptions $(73,74)$.

\section{CONCLUSIONS AND FUTURE CONSIDERATIONS}

Norwegian social epidemiology has shown that the socioeconomic conditions people live under have a major impact on public health in Norway. For many, the findings have been surprising, not least considering fairly small income disparities and the welfare political developments we have seen in the postwar period. However, the major social differences in health-related behaviors still have great significance and are challenging to reduce as long as the authorities are reluctant to use policy measures $(75,76)$.

Future social epidemiology is vital in terms of monitoring social inequalities in health, collect new research data and study the impact of socioeconomic changes in the population on population health (77). Health-related behaviors are changing, some behaviors disappear and new ones appear. In order to reduce the unfair and avoidable inequalities in health in the population, we must at all times have updated knowledge from updated data about the relevant social determinants of health.

\section{REFERENCES}

1. Berkman LF, Kawachi I. A historical framework for social epidemiology. In: Berkman LF, Kawachi I, eds. Social Epidemiology. Oxford: Oxford University Press, 2000.

2. Rose G. Sick individuals and sick populations. Int J Epidemiol 2001; 30: 427-32.

3. Davey Smith G. Epidemiology, epigenetics and the 'Gloomy Prospect': embracing randomness in population health research and practice. Int J Epidemiol 2011; 40 (3): 537-62.

4. Adler NE, Boyce T, Chesney MA, Cohen S, Folkman S, Kahn RL, et al. Socioeconomic status and health. The challenge of the gradient. Am Psychol 1994; 49 (1): 15-24.

5. Diez-Roux AV. Bringing context back into epidemiology: variables and fallacies in multilevel analysis. Am $J$ Public Health 1998; 88 (2): 216-22.

6. Næss $\varnothing$, Piro FN, Nafstad P, Smith GD, Leyland AH. Air pollution, social deprivation, and mortality: a multilevel cohort study. Epidemiology 2007; 18 (6): 686-94.

7. Krieger N. Historical roots of social epidemiology: socioeconomic gradients in health and contextual analysis. Int J Epidemiol 2001; 30: 899-900.

8. Næss $\varnothing$, Schiøtz A. Commentary: Kristian Feyer Andvord's studies on the epidemiology of tuberculosis and the origin of generation cohort analysis. Int J Epidemiol 2008; 37 (5): 923-32.

9. Forsdahl A. Are poor living conditions in childhood and adolescence an important risk factor for arteriosclerotic heart disease? Int J Rehabil Res 1979; 2 (2): 238-9.

10. Forsdahl A. Observations throwing light on the high mortality in the county of Finnmark. Is the high mortality today a late effect of very poor living conditions in childhood and adolescence? Int J Epidemiol 2002; 31 (2): 302-8. 
11. Engels F. The Condition of the Working-Class in England in 1844. London: Swann and Sonnenschien, 1892.

12. Townsend P, Davidson N. Inequalities in health. The Black Report. Harmondsworth: Penguin books, 1982.

13. Borgan JK, Kristofersen LB. Mortality by occupation and socio-economic group in Norway 1970-1980. Oslo, Central Bureau of Statistics, 1986.

14. Holme I, Helgeland A, Hjermann I, Lund-Larsen PG, Leren P. Coronary risk factors and socioeconomic status. The Oslo Study. Lancet 1976; 25: 1396-8.

15. Marmot M, Rose G, Shipley MJ, Hamilton PJS. Employment grade and coronary heart disease in British civil servants. J Epidemiol Community Health 1978; 32: 244-9.

16. Sundt E. Om dødeligheden i Norge - bidrag til kundskap om folkets kaar. Christiania: Mallings Bogtrykkeri, 1855.

17. Backer J. Dødeligheten og dens årsaker i Norge, 1856-1955. Oslo: Statistisk sentralbyrå, 1961.

18. Hansen FH, Reitan J-E. Helse- og levekårsatlas for Hordaland og Noreg. Bergen: Hordaland Fylkeskommune og Norsk samfunnsvitenskapelig datatjeneste (NSD), 1996.

19. Aase A. Nasjonalatlas for Norge: Helse. Hønefoss: Statens kartverk, 1996.

20. Glattre E, Finne TE, Olesen O, Langmark F. Atlas over kreftinsidens i Norge 1970-79. Oslo: Kreftregisteret og Landsforeningen mot kreft, 1985.

21. Gjestland T, Moen E, Trier G. En regional undersøkelse av dødeligheten i Oslo 1890-1940. Oslo: Statitics Norway, 1954. Report No. 44.

22. Gjestland T, Moen E. East is east and west is west. En sammenliknende undersøkelse av dødeligheten i Oslo øst og Oslo vest i perioden 1890-1940 og 1971-1980. Oslo: Norsk institutt for by- og regionforskning, 1988. Report No. 21.

23. Mæland JG, Elstad JI, Næss Ø, Westin S, eds. Sosial epidemiologi. Sosiale årsaker til sykdom og helsesvikt. Oslo: Gyldendal akademisk, 2009.

24. Commision on Social Determinants of Health. Closing the gap in a generation. Health equity through action on the social determinants of health. Geneva: WHO, 2008.

25. Nasjonal strategi for å utjevne sosiale helseforskjeller. Det kongelige helse- og sosialdepartement, 2006.

26. Dahl E, Bergsli H, van der Wel KA. Sosial ulikhet i helse: En norsk kunnskapsoversikt. Oslo: Høgskolen i Oslo og Akershus, 2014.

27. Strand BH, Grøholt EK, Steingrímsdóttir ÓA, Blakely T, Graff-Iversen S, Næss Ø. Educational inequalities in mortality over four decades in Norway: prospective study of middle aged men and women followed for cause specific mortality, 1960-2000. BMJ 2010; 340: c654.

28. Krokstad S, Kunst AE, Westin S. Trends in health inequalities by educational level in a Norwegian total population study. J Epidemiol Community Health 2002; 56: 375-80.

29. Ernstsen L, Strand BH, Nilsen SM, Espnes GA, Krokstad S. Trends in absolute and relative educational inequalities in four modifiable ischaemic heart disease risk factors: repeated cross-sectional surveys from the Nord-Trøndelag Health Study (HUNT) 1984-2008. BMC Public Health 2012; 12: 266.

30. Cavelaars AE, Kunst AE, Geurts JJ, Crialesi R, Grotvedt L, Helmert U, et al. Educational differences in smoking: international comparison. BMJ 2000; 320 (7242): 1102-7.

31. Strand BH, Næss Ø. Folkehelsens sosioøkonomiske fordeling. In: Mæland JG, Elstad JI, Næss Ø, Westin S, eds. Sosialepidemiologi. Sosiale årsaker til sykdom og helsesvikt. Oslo: Gyldendal akademisk, 2009: 59-80.

32. Krieger N. A glossary for social epidemiology. J Epidemiol Community Health 2001; 55: 693-700.

33. Brunner E. Stress and the biology of inequality. BMJ 1997; 314: 1472-6.

34. Dahl E. Social inequalities in ill-health. The significance of occupational status, education and income. Results from a Norwegian survey. Sociol Health Illness 1991; 16: 492-505.

35. Elstad JI, Dahl E. Er inntektsulikhet en selvstendig risikofaktor for dødelighet? In: Mæland JG, Elstad JI, Næss Ø, Westin S, eds. Sosialepidemiologi. Sosiale årsaker til sykdom og helsesvikt. Oslo: Gyldendal akademisk, 2009: 193-209.

36. Lynch JW, Kaplan GA. Understanding how inequality in the distribution of income affects health. $J$ Health Psychol 1997; 2 (3): 297-314.

37. Wilkinson RG. Income inequality, social cohesion, and health: clarifying the theory - a reply to Muntaner and Lynch. Int J Health Serv 1999; 29 (3): 525-43.

38. Marmot M. Status syndrom. How your social standing directly affects your health and life expectancy. London: Bloomsbury, 2004.

39. Wilkinson RG, Pickett KE. The Spirit Level: Why equality is better for everyone. London: Penguin Books, 2010.

40. Dahl E. Sosial ulikhet i helse: Artefakter eller seleksjon? University of Oslo, 1994.

41. Elstad JI. Social inequalities in health and their explanations. NOVA, 2000. 
42. Dahl E, Elstad JI. Kan helserelatert seleksjon forklare sosial ulikhet i helse? In: Mæland JG, Elstad JI, Næss $\varnothing$, Westin S, eds. Sosialepidemiologi. Sosiale årsaker til sykdom og helsesvikt. Oslo: Gyldendal akademisk, 2009: 249-65.

43. Hofoss D, Dahl E, Elstad JI, Cvancarova M. Selection and mortality: a ten-year follow-up of income decile mortality in Norway. Eur J Public Health 2013; 23 (4): 558-63.

44. Elstad JI, Krokstad S. Social causation, health-selective mobility, and the reproduction of socioeconomic health inequalities over time: panel study of adult men. Soc Sci Med 2003; 57 (8): 1475-89.

45. Gravseth HM, Bjerkedal T, Irgens LM, Aalen OO, Selmer R, Kristensen P. Life course determinants for early disability pension: a follow-up of Norwegian men and women born 1967-1976. Eur J Epidemiol 2007; 22 (8): 533-43.

46. Link BG, Phelan JC, Miech R, Westin EL. The resources that matter: fundamental social causes of health disparities and the challenge of intelligence. J Health Soc Behav 2008; 49 (1): 72-91.

47. Mackenbach JP, Kulhanova I, Bopp M, Deboosere P, Eikemo TA, Hoffmann R, et al. Variations in the relation between education and cause-specific mortality in 19 European populations: A test of the "fundamental causes" theory of social inequalities in health. Soc Sci Med 2015; 127: 51-62.

48. Krieger N. Theories for social epidemiology in the 21 st century: an ecosocial perspective. Int J Epidemiol 2001; 30: 668-77.

49. Kristensen P, Mehlum IS, Gravseth HM. Arbeid og yrke: Helsefremmende og helseskadelige faktorer. In: Mæland JG, Elstad JI, Næss Ø, Westin S, eds. Sosialepidemiologi. Sosiale årsaker til sykdom og helsesvikt. Oslo: Gyldendal akademisk, 2009: 152-69.

50. Krokstad S, Westin S. Disability in society. Medical and non-medical determinants for disability pension in a Norwegian total county population study. Soc Sci Med 2004; 58: 1837-48.

51. Krokstad S, Johnsen R, Westin S. Social determinants of disability pension: a 10-year follow-up of 62000 people in a Norwegian county population. Int J Epidemiol 2002; 31: 1183-91.

52. Nilsen SM, Ernstsen L, Krokstad S, Westin S. Educational inequalities in disability pensioning - the impact of illness and occupational, psychosocial, and behavioural factors: The Nord-Trøndelag Health Study (HUNT). Scand J Public Health 2012; 40 (2): 133-41.

53. Hart JT. The inverse care law. Lancet 1971; 1 (7696): 405-12.

54. Vikum E, Bjørngaard JH, Westin S, Krokstad S. Socio-economic inequalities in Norwegian health care utilization over 3 decades: the HUNT Study. Eur J Public Health 2013, 23 (6): 1003-10.

55. Hansen AH, Halvorsen PA, Ringberg U, Førde OH. Socio-economic inequalities in health care utilisation in Norway: a population based cross-sectional survey. BMC Health Serv Res 2012; 12: 336.

56. Wennberg JE. Tracking medicine. A researcher's quest to understand health care. Oxford: Oxford University Press, 2010.

57. Hansen AH, Halvorsen PA, Aaraas IJ, Førde OH. Continuity of GP care is related to reduced specialist healthcare use: a cross-sectional survey. Br J Gen Pract 2013; 63 (612): 482-9.

58. Westin S. Velferd og helse i folketrygdens århundre (Welfare and health in the century of social security). Tidsskr Nor Lageforen 1999; 119: 4507-13.

59. van der Wel KA, Dahl E, Thielen K. Social inequalities in 'sickness': European welfare states and nonemployment among the chronically ill. Soc Sci Med 2011; 73 (11): 1608-17.

60. Lundberg O, Yngwe MA, Stjärne MK, Björk L, Fritzell J. The Nordic experience: welfare states and public health. Final Report from the NEWS-Project. Stockholm: CHESS, 2008.

61. Lundberg O, Yngwe MA, Stjärne MK, Elstad JI, Ferrarini T, Kangas O, et al. The role of welfare state principles and generosity in social policy programmes for public health: an international comparative study. Lancet 2008; 372 (9650): 1633-40.

62. Fritzell J, Kangas O, Bacchus HJ, Blomgren J, Hiilamo H. Cross-temporal and cross-national poverty and mortality rates among developed countries. J Environ Public Health 2013; 915490.

63. Dalgard OS, Sørensen T. Sosialt nettverk, sosial støtte og nærmiljø - viktige faktorer for helsen. In: Mæland JG, Elstad JI, Næss Ø, Westin S, eds. Sosialepidemiologi. Sosiale årsaker til sykdom og helsesvikt. Oslo: Gyldendal akademisk, 2009: 96-114.

64. Dalgard OS, Lund HL. Psychosocial risk factors and mortality: a prospective study with special focus on social support, social participation, and locus of control in Norway. J Epidemiol Community Health $1998 ; \mathbf{5 2}$ (8): 476-81.

65. Dalgard OS, Dowrick C, Lehtinen V, Vazquez-Barquero JL, Casey P, Wilkinson G, et al. Negative life events, social support and gender difference in depression: a multinational community survey with data from the ODIN study. Soc Psychiatry Psychiatr Epidemiol 2006; 41 (6): 444-51.

66. Wilkinson RG. Unhealthy societies: the afflictions of inequality. London: Routledge, 1996. 
67. Sund ER, Krokstad S. Sosial kapital. Limet som holder folkehelsen sammen? In: Mæland JG, Elstad JI, Næss Ø, Westin S, eds. Sosial epidemiologi. Sosiale årsaker til sykdom og helsesvikt. Oslo: Gyldendal Norsk Forlag, 2009: 115-35.

68. Sund ER, Jørgensen SH, Jones A, Krokstad S, Heggdal M. The influence of social capital on self-rated health and depression - The Nord-Trøndelag Health Study (HUNT). Nor Epidemiol 2007; 17 (1): 59-69.

69. van der Wel KA. Social capital and health - a multilevel analysis of 25 administrative districts in Oslo. Nor Epidemiol 2007; 17 (1): 71-8.

70. Langhammer A, Krokstad S, Romundstad P, Heggland J, Holmen J. The HUNT study: participation is associated with survival and depends on socioeconomic status, diseases and symptoms. BMC Med Res Methodol 2012; 12: 143.

71. Jenum AK. Etniske og kulturelle faktorers betydning for helse. In: Mæland JG, Elstad JI, Næss Ø, Westin S, eds. Sosialepidemiologi. Sosiale årsaker til sykdom og helsesvikt. Oslo: Gyldendal akademisk, 2009: 170-92.

72. Nissen-Meyer M, Shuja AL, Sletnes T. Likeverdig helsetjeneste? - Om helsetjenester til ikke-vestlige innvandrere. Oslo: Den norske legeforening, 2008.

73. Næss Ø, Rognerud MAa, Strand BH. Sosial ulikhet i helse. En faktarapport. Oslo: Nasjonalt folkehelseinstitutt, 2007.

74. Jenum AK, Holme I, Graff-Iversen S, Birkeland KI. Ethnicity and sex are strong determinants of diabetes in an urban Western society: implications for prevention. Diabetologia 2005; 48 (3): 435-9.

75. Whitehead M. The concepts and principles of equity and health. Int J Health Serv 1992; 22 (3): 429-45.

76. Giæver $\varnothing$, Torgersen TP. Fra forskning til politikk: Utvikling av en nasjonal strategi mot sosiale helseforskjeller. In: Mæland JG, Elstad JI, Næss Ø, Westin S, eds. Sosial epidemiologi. Sosiale årsaker til sykdom og helsesvikt. 1 ed. Oslo: Gyldendal akademisk, 2009: 339-57.

77. Strand BH, Steingrímsdóttir ÓA, Grøholt EK, Ariansen I, Graff-Iversen S, Næss Ø. Trends in educational inequalities in cause specific mortality in Norway from 1960 to 2010: a turning point for educational inequalities in cause specific mortality of Norwegian men after the millennium? BMC Public Health 2014; $14: 1208$. 